\title{
Deteksi Dini Penyakit Gout Pada Lansia di Wilayah Kerja Puskesmas Kalibaru Bekasi
}

\author{
Ria Amelia*1, Elfira Mayasari², Siti Nurfajriah ${ }^{3}$, Maulin Inggraini4, Intan K.Pramitaningrum ${ }^{5}$ \\ ${ }^{12345}$ Program Studi DIII Teknologi Laboratorium Medis, STIKes Mitra Keluarga, Jalan Pengasinan, Rawa \\ Semut, Margahayu Bekasi Timur 17113 \\ *e-mail: riacaramel@gmail.com,ria.amelia@stikesmitrakeluarga.ac.id
}

\begin{abstract}
Gout caused by hyperuricemia is a condition of high of uric acid in the blood. The condition of hyperuricemia in elderly is related to metabolic syndrome which is caused by slow rate of the body's metabolism. This activity aims to determine a prevalence of hyperuricemia in elderly at four Posbindu as a working area of Kalibaru Health Center. Type of research is cross sectional with a simple random sampling method. The activity was carried out in August 2019. The method to measurement of uric acid levels by the strip method. The Descriptive test results showed a modus of the elderly is at the age of 65 years and the oldest at the age of 89 years. The percentage of elderly people who experience hyperuricemia based on WHO 2013 criteria as many as $8.8 \%$ from a total of 68 elderly. The conclusion of this activity indicates that $90 \%$ of elderly in the working area of the Kalibaru Helath Center have normal of uric acid levels.
\end{abstract}

Keywords: Uric Acid, Hyperuricemia, Elderly and Puskesmas Kalibaru.

\begin{abstract}
Abstrak
Gout diakibatkan karena hiperurisemia yang merupakan kondisi tingginya kadar asam urat dalam darah. Kondisi ini umum ditemukan pada lansia akibat lambatnya laju metabolisme tubuh. Kegiatan ini bertujuan untuk mengetahui prevalensi hiperurisemia pada lansia di empat posbindu wilayah kerja puskesmas kalibaru. Jenis penelitian cross sectional dengan metode pengambilan sampel acak sederhana. Kegiatan dilakukan pada bulan agustus 2019. Pengukuran kadar asam urat dengan metode strip. Hasil uji deskriptif modus pada lansia usia 65 tahun dan tertua pada usia 89 tahun. Persentase lansia yang mengalami hiperurisemia berdasarkan kriteria WHO 2013 sebanyak 8.8 \% dari total lansia 68 orang. kesimpulan dari kegiatan ini menunjukkan 90\% lansia yang berada di wilayah kerja puskesm kalibaru memiliki kadar asam urat bernilai normal.
\end{abstract}

Kata kunci: Asam urat, Hiperurisemia, Lansia dan Puskesmas Kalibaru.

\section{PENDAHULUAN}

Asam urat merupakan produk katabolisme dari nukleotida purin. Asam urat pada tubulus proksimal di reabsorbsi kembali oleh tubuh dan 1.7\% dikeluarkan melalui urin. Asam urat tidak larut dalam plasma dan pada konsentrasi yang tinggi dapat berkumpul dipersendian dan jaringan sehingga menyebabkan sakit. Pemeriksaan asam urat digunakan untuk konfirmasi diagnosis dan monitor pengobatan asam urat, mencegah nefropati asam urat selama perawatan kemoterapi, menilai gangguan metabolisme purin akibat keturunan, mendeteksi disfungsi ginjal, dan membantu dalam diagnosis batu ginjal (Bishop, M., et al., 2013). Berdasarkan Undang-undang No.13 Tahun 1998 tentang kesejahteraan lansia menetapkan bahwa batasan umur lansia di Indonesia adalah 60 tahun ke atas. Artritis menduduki urutan kedua masalah kesehatan lansia di Indonesia (Infodatin, 2016). Artritis merupakan penyakit peradangan pada nyeri sendi dapat satu atau beberapa sendi yang disebabkan oleh beberapa faktor yaitu autoimun, faktor metabolik, infeksi patogen, kecelakaan, rokok, usia, jenis kelamin dan genetik. Berdasarkan faktor penyebabnya arthritis dibagi empat macam yaitu osteoarthritis, rheumatoid arthritis, gout (asam urat), fibromyalgia (Adams, T.L., and Marchiori, D. M., 2014).

Gout salah satu jenis arthritis yang menyebabkan rasa sangat sakit dan pembengkakkan akibat dari inflamasi dan terjadi pada satu titik. Gout disebabkan oleh hiperurisemia (Barry L.H., Eric M. and R. Travis W., 2014). Hiperurisemia merupakan kondisi tingginya asam urat dalam darah. Gout biasa diderita oleh lansia pria berumur 65 tahun dan wanita berumur 85 tahun. Faktor dominan yang menyebabkan encok pada lansia yaitu asupan protein, obesitas, hipertensi, 
penggunaan diuretik, fungsi ginjal dan genetik (Bruke, B.T. et al., 2015). Populasi lansia di Indonesia meningkat. Peningkatan tersebut harus diimbangi dengan peningkatan pelayanan kesehatan terhadap lansia untuk mewujudkan lansia sehat, mandiri, berkualitas dan produktif. Tujuh program kesehatan lansia di Puskesmas merupakan kebijakan pemerintah untuk melaksanakan kebijakan tersebut (Infodatin, 2016). Pemeriksaan kesehatan yang rutin dapat mencegah terjadinya penyakit metabolik seperti kadar C-Reactive Protein dan Kreatinin sebagai tanda adanya inflamasi pada ginjal (Amelia, R., et al., 2019). Puskesmas Kalibaru terletak di Keluarhan Kalibaru, Kecamatan Medan Satria Kota Bekasi. Dalam menjalankan ketujuh program ini Puskesmas khususnya Puskesmas Kalibaru bekerjasama dengan Prodi DIII Teknologi Laboratorium Medis STIKes Mitra keluarga mengadakan kegiatan program pengabdian masyarakat dibeberapa Pos Binaan Terpadu (POSBINDU) guna mencegah terjadinya penyakit gout yang dapat mengganggu aktivitas lansia dan berisiko terbentuknya batu ginjal dengan melakukan dengan melakukan pemeriksaan kadar asam urat. Adapun wilayah kerja puskesmas Kalibaru yang dijadikan tempat untuk kegiatan ini yaitu wilayah 10 RW yaitu 02, 03, 05, 06, 07, 09, $10,11,25,26$ kecamatan medan satria kota Bekasi

\section{METODE}

Jenis penelitian cross sectional dengan metode pengambilan sampel acak sederhana. Kegiatan sesuai dengan surat tugas No.003/STIKes.MK/PPPM/SK-PKM/VIII/2019 ttg Penetapan Kegiatan PKM Prodi DIII Analis Kesehatan STIKes Mitra Keluarga dilaksanakan pada bulan agustus 2019 diempat POSBINDU binaan Puskesmas Kalibaru wilayah kecamatan medan satria kota Bekasi yaitu Posbindu Anggrek yang mencakup RT/RW: 01/07,02/07, 03/06, dan 02/03, Teratai I yang mencakup wilayah RT/RW: 04/02, 01/10, 03/10, 04/10, 05/10, 06/10, 07/10. 07/25, 02/09, 01/03, 06/11, 01/26/, dan 03/05. Mawar yang mencakup wilayah RT/RW: 01/09, 02/09, 03/09, 04/09, dan 05/09 dan Dahlia yang mencakup wilayah RT/RW: 01/06, 02/06, 03/06, dan 04/06. Pemilihan POSBINDU dipilih secara acak. Mekanisme pemeriksaan dibantu oleh kader posbindu setempat dengan melakukan pendataan nama, umur, tempat tinggal dan pengambilan nomor antri pemeriksaan. Pasien lansia yang berusia 60 ke atas diarahkan untuk melakukan pemeriksaan asam urat. Setelah mendapatkan hasil pemeriksaan asam urat, pasien berkonsultasi ke dokter puskesmas yang bertugas. Pengukuran asam urat menggunakan Point of Care Testing (POCT) Easy Touch GCU Chek dengan metode dehydrohidrase. Prinsip pemeriksaan darah diserap ke dalam strip tes, kemudian mengalir ke area tes dan bercampur dengan reagen yang terdapat pada strip. Enzim dehydrogenase dan koenzim dalam strip mengkonversi glukosa dan asam urat dalam sampel darah menjadi glukonolakton dan oksidasi asam urat. Reaksi tersebut menghasilkan listrik DC yang tidak berbahaya dan meter mampu mengukur kadar asam urat (Purwaningsih, 2017).

\section{HASIL DAN PEMBAHASAN}

Kegiatan pengabdian masyarakat ini dilaksanakan diempat POSBINDU pada waktu yang telah diagendakan untuk pemeriksaan kesehatan rutin yang dilakukan petugas Puskesmas Kalibaru dengan kader POSBINDU. Pada setiap POSBINDU terdapat kader yang merupakan ibuibu warga setempat. Kader POSBINDU berperan penting dalam terlaksananya kegiatan ini seperti menyediakan tempat yang layak untuk dilakukan pemeriksaan kesehatan, menginformasikan warga setempat yang memiliki lansia agar datang pada waktu dan tempat yang telah ditentukan. Kontribusi lansia pada wilayah ini merupakan orang tua dari setiap keluarga yang rata-rata memiliki kegiatan rumahan seperti bertanam, mengurus cucu, dan mengaji. Selain itu, kader juga membantu dalam mengatur urutan pemeriksaan warga. Hasil pemeriksaan asam urat akan keluar 1 menit setelah dilakukan pemeriksaan. Pencatatan hasil dilakukan 2 kali yaitu satu kertas hasil diberikan untuk warga dan satu untuk data yang akan dilaporkan ke petugas puskesmas. Adanya peranan warga dalam kegiatan pemeriksaan kesehatan membuat warga membuka wawasan pengetahuan tentang pentingnya melakukan pemeriksaan kesehatan rutin (Nita, V., \& Inrayani, 
N., 2020). Gambar 1. di bawah ini menunjukkan gambaran kegiatan dilakukan di keempat POSBINDU.

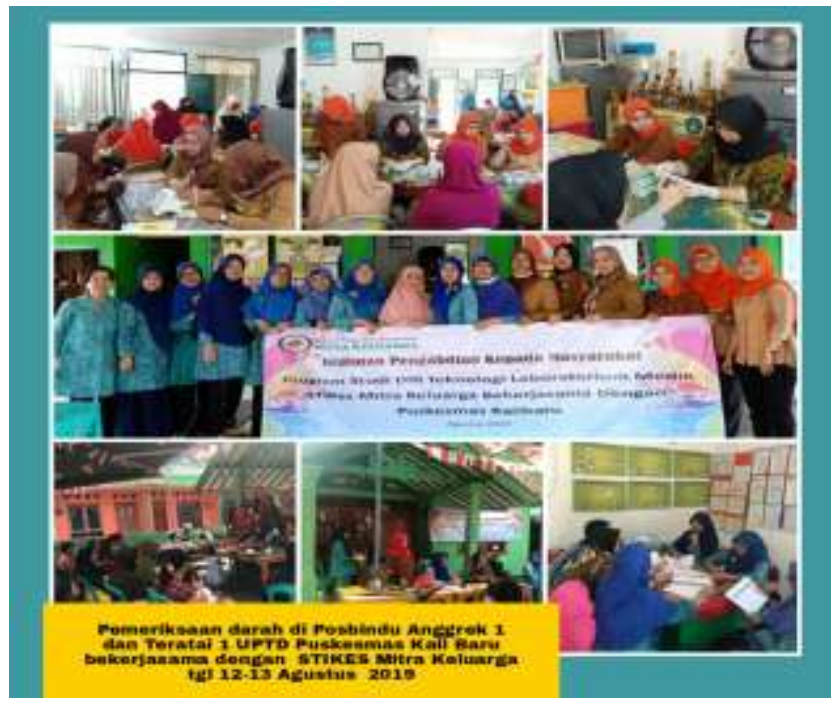

(a.)

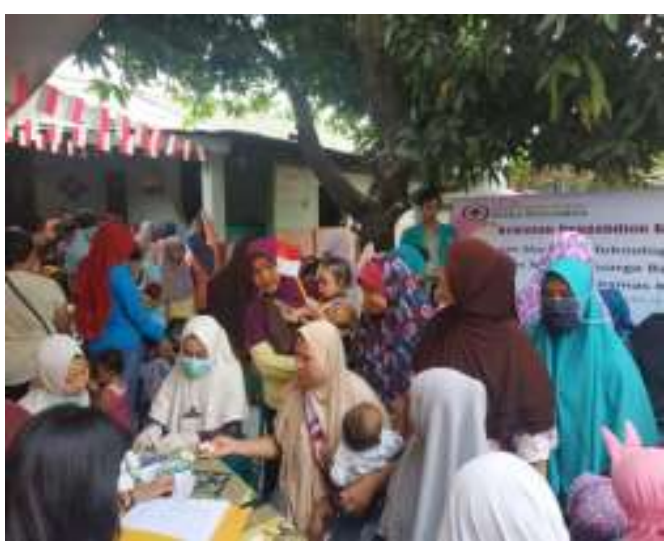

(b.)

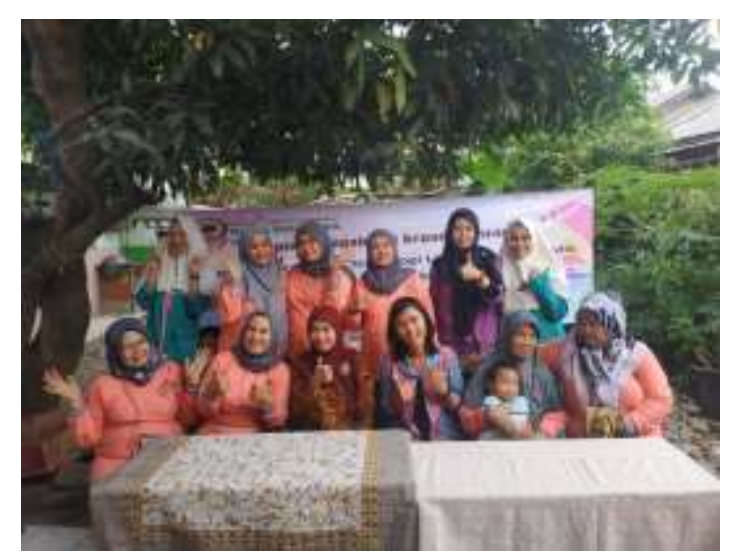

(c.)

Gambar 1. Kegiatan Pemeriksaan asam urat diempat POSBINDU binaan Puskesmas Kalibaru (a) POSBINDU Anggrek 1 dan Teratai 1. (b) POSBINDU Mawar. (c) POSBINDU Dahlia.

Pengecekkan kualiti Kontrol kinerja alat POCT Easy Touch GCU Chek untuk melakukan pemeriksaan asam urat dilakukan satu minggu sebelum pemeriksaan guna menghindari kesalahan terhadap pembacaan hasil. Kualiti kontrol dilakukan dengan membandingkan hasil pemeriksaan asam urat dengan dua metode pemeriksaan yang berbeda yaitu metode POCT dan metode spektrofotometer. Perbandingan dua metode berbeda dibutuhkan untuk mendapatkan hasil yang akurat dan tepat sesuai dengan kebutuhan (Amelia, R. \& Luhulima, D., 2020) Perawatan dan kalibrasi alat kesehatan secara rutin sangat penting karena hasil dari pemeriksaan mempengaruhi diagnosa (Susana, E., 2020) Hasil pemeriksaan asam urat diempat POSBINDU binaan Puskesmas Kalibaru menunjukkan bahwa responden didominasi oleh lansia perempuan sebanyak 55 orang $(80.9 \%)$ dengan rata-rata usia 66 tahun. Usia responden terbanyak 65 tahun, usia termuda 60 tahun dan tertua 89 tahun. Hasil pengukuran asam urat menunjukkan nilai ratarata $5.9 \mathrm{mg} / \mathrm{dL}$, modus $5.5 \mathrm{mg} / \mathrm{dL}$, maksimal $10.7 \mathrm{mg} / \mathrm{dL}$ dan nilai minimal $3.5 \mathrm{mg} / \mathrm{dL}$. Hal ini dapat dilihat pada Tabel 1. dibawah ini. Nilai asam urat rata-rata lansia masih tergolong normal sehingga pola hidup sehat pada lansia diwilayah ini perlu dipertahankan. Bagi lansia yang memiliki nilai diatas normal $8.0 \mathrm{mg} / \mathrm{dL}$ (WHO, 2013) disarankan untuk menghindari makan yang mengandung protein purin tinggi seperti kacang-kacangan, sayuran hijau seperti kangkung, dan 
jeroan sapi (Asbar A. dan Marti, M, 2018). Disamping itu, diperlukan pemeriksaan asam urat yang rutin untuk mengetahui efektivitas dari diet makanan yang telah dilakukan apakah berpengaruh terhadap penurunan kadar asam urat darah.

Tabel 1. Hasil Univariat

\begin{tabular}{lcccc}
\hline Variabel & \multicolumn{4}{c}{ Hasil $(\mathrm{n}=68)$} \\
\hline Jenis Kelamin & Wanita $=55$ & \multicolumn{2}{c}{ Pria= 13 } \\
& $(80.9 \%)$ & $(19.1 \%)$ \\
& Mean & Modus & Min. & Max \\
Usia (tahun) & 66.84 & 65 & 60 & 89 \\
Asam Urat (mg/dL) & 5.9 & 5.5 & 3.5 & 10.7 \\
\hline
\end{tabular}

Hiperurisemia berdasarkan kriteria WHO 2013 pada lansia yaitu wanita $>8.0 \mathrm{mg} / \mathrm{dL}$ dan pria $>8.5 \mathrm{mg} / \mathrm{dL}$. Tabel 2. dibawah ini menunjukkan lansia yang mengalami hiperurisemia berusia diatas 60 tahun dan berada di wilayah Posbindu Teratai1 dan Mawar. Wilayah Posbindu Anggrek 1 dan Dahlia tidak terdapat lansia yang kadar asam uratnya melebihi batas normal kriteria WHO 2013.

Tabel 2. Responden Lansia Hiperurisemia

\begin{tabular}{clccc}
\hline No. & Sampel & $\begin{array}{c}\text { Usia } \\
\text { (tahun) }\end{array}$ & $\begin{array}{c}\text { Kadar Asam urat } \\
(\mathrm{mg} / \mathrm{dL})\end{array}$ & Posbindu \\
\hline 1. & Ny. S & 62 & 10.7 & Teratai 1 \\
2. & Ny.R & 70 & 8.4 & Teratai 1 \\
3. & Ny. SS & 68 & 9.6 & Teratai 1 \\
4. & Tn.S & 61 & 8.9 & Teratai 1 \\
5. & Ny. A & 67 & 9.8 & Mawar \\
6. & Ny.T & 65 & 9.1 & Mawar \\
\hline
\end{tabular}

Berdasarkan Tabel 2. maka persentase lansia yang berkadar asam urat normal sebanyak 62 orang (91.2\%) dan 6 orang ( $8.8 \%$ ) mengalami hiperurisemia dari total lansia 68 orang. Pada Tabel 2. menunjukkan jenis kelamin lansia yang mengalami hiperurisemia berjenis kelamin perempuan. Kadar asam urat dipengaruhi oleh jenis kelamin dan usia. Pria memiliki kadar asam urat yang lebih tinggi dari wanita. Hal ini dikarenakan hormon testosterone pada pria dapat meningkatkan eksresi asam urat pada ginjal sedangkan hormon estradiol menekan eksresi asam urat (Kurahashi H., et al., 2013). Kadar hormon testosterone akan menurun sejak usia di atas 30 tahun (Zirkin, B.R. \& Joyce, L.T., 2012). Penurunan kadar testostetrone diikuti dengan penurunan hormon estradiol yang lebih rendah pada pria (Wu A., et al., 2011). Penurunan ini disebabkan karena sel leydig pada testis menua (Zirkin, B.R. \& Joyce, L.T., 2012). Selain faktor usia, penurunan kedua hormon ini juga berhubungan dengan obesitas (Wu A., et al., 2011). Hal ini sesuai dengan hasil penelitian yang diperoleh pada Tabel 1 dimana responden wanita lebih banyak daripada pria dan pada Tabel 2 hanya terdapat 1 pria saja yang mengalami hiperurisemia. Bagi lansia yang telah terdeksi mengalami hiperurisemia telah dikonsulkan ke dokter puskesmas untuk diberikan pengobatan. Selain itu, untuk membantu optimalisasi pengobatan maka disarankan untuk mengkonsumsi minum air putih, meminum susu rendah lemak, membatasi asupan makanan berprotein yang tinggi (Asbar A. dan Marti, M, 2018).

Pada wanita estradiol berfungsi untuk pematangan sistem reproduksi. Ketika masa produktif kadar estradiol meningkat, namun masa menopause kadar estradiol menurun dratis (Yuichi T., et al., 2011). Masa menopause wanita pada umumnya dimulai sejak usia 45 dan 
mencapai puncak pada usia 50 tahun (Asbar, A. dan Marty, M., 2018). Berdasarkan hal tersebut mayoritas responden sudah menopause dengan usia minimal berusia 60 tahun dan maximal 89 tahun (Tabel. 1). Hormon estradiol menekan eksresi asam urat dengan cara menekan kadar protein urate reabsortive transporters transporter 1 dan glucose transporter 9 (Urat 1dan Glu9) (Kurahashi H., et al., 2013, Yuichi T., et al., 2011). Berdasarkan hal tersebut wanita yang mengalami masa menopause memiliki peluang besar mengalami hiperurisemia (Cho, S. K., 2019). Hal ini didukung dari hasil responden (Tabel 1 dan Tabel 2) yang diperoleh mayoritas bergender wanita dan 5 responden mengalami hiperurisemia.

Hiperusemia dapat meningkatkan massa indeks tubuh, tekanan sistol diastole, gula darah puasa, trigliserid, low-density lipoprotein (LDL), High-density lipoprotein (HDL), Alanine aminotransferase (ALT), Blood Urea Nitrogen (BUN), dan kreatinin (Ni Q., et al., 2019). Kenaikan nilai tersebut jika dibiarkan dapat mengakibatkan penyakit tidak menular seperti jantung koroner, diabetes mellitus tipe 2, stroke, dan ginjal kronis (Yu, X. L., 2017). Hal ini dikarenakan tubuh memiliki mekanisme homeostatis untuk mempertahan metabolisme secara normal. Namun, jika kondisi seperti kadar haemoglobin rendah, hiperurisemia, hiperglikemia terlalu lama maka tubuh akan mengalami kondisi patologis yang dapat menyebabkan penyakit kronik (Ramadhanti M., et. al., 2018). Berdasarkan Hasil Riskesdas tahun 2018 pada provinsi Jawa Barat terjadi peningkatan kasus stroke, ginjal kronis, diabetes mellitus, jantung, hipertensi pada usia diatas 15 tahun dari tahun 2013 sampai 2018 (Badan Penelitian dan Pengembangan Kesehatan, 2018). Hal ini menunjukkan pentingnya dilakukan pemeriksaan asam urat secara berkala terutama pada lansia untuk menghindari terjadinya penyakit tidak menular yang akan berdampak terhadap kesejahteraan dan kualitas hidup lansia.

\section{KESIMPULAN}

Kegiatan pengabdian masyarakat dengan melakukan pengukuran asam urat dengan metode POCt pada lansia di wilayah binaan Puskesmas Kalibaru wilayah kecamatan medan satria kota Bekasi yaitu Posbindu Anggrek yang mencakup RT/RW: 01/07,02/07, 03/06, dan 02/03, Teratai I yang mencakup wilayah RT/RW: 04/02, 01/10, 03/10, 04/10, 05/10, 06/10, 07/10. 07/25, 02/09, 01/03, 06/11, 01/26/, dan 03/05. Mawar yang mencakup wilayah RT/RW: 01/09, 02/09, 03/09, 04/09, dan 05/09 dan Dahlia yang mencakup wilayah RT/RW: 01/06, 02/06, 03/06, dan 04/06 diperoleh prevalensi lansia yang mengalami hiperurisemia pada empat posbindu di wilayah kerja puskesmas kalibaru sebanyak 6 lansia ( $8.8 \%$ ) dari total peserta 68 lansia. Kondisi Hiperurisemia mayoritas ditemukan pada lansia perempuan sebanyak 5 lansia dan wilayah yang memiliki lansia hiperurisemia terbanyak yaitu di wilayah posbindu teratai 1 .

\section{UCAPAN TERIMA KASIH}

Terima Kasih kepada PUSKESMAS KALIBARU dan DINAS KESEHATAN BEKASI atas perijinan dan kerjasamanya sehingga kegiatan pengabdian kepada masyarakat dapat berjalan dengan baik dan lancer.

\section{DAFTAR PUSTAKA}

Adams, T.L., \& Marchiori, D. M. (2014). Chapter 9 Arthritides. Clinical Imaging (3th edition). United State: Elsevier Inc. doi:10.1016/b978-0-323-08495-6.00009-9.

Alyensi, F \& Ani Laila. (2019). Pembentukan dan Pelaksanaan Kelompok Pendukung ASI (KP ASI) di RW 2 Kelurahan Sialang Sakti Wilayah Kerja PUSKESMAS Rejosari Kecamatan Tenayan Raya Pekanbaru Tahun 2019. Dinamisia: Jurnal Pengandian Kepada Masyarakat, 3(2), 299304. 
Amelia, R., \& Luhulima, D. (2020). Relationship Between Levels of Fasting Blood Glucose and HbA1C in Prediabetes Patients. Proceeding $2^{\text {nd }}$ Bakti Tunas Husada-Health Science International Conference, (26): 1-4.

Amelia, R., N. Arshita., SN. Fajriah., C.V.D. Astuti., I.N. Fitri. 2019. A Sign Of Acute Inflammation In Type 2 Diabetes Mellitus Patients In Kota Baru And Kalibaru Subdistricts, Bekasi. ActaBiolna, 2(2): 45-51.

Asbar, A. dan Marty, M. (2018). Hidup Berkualitas: Studi Kasus Pada Perempuan Menopouse. Marwah: Jurnal Perempuan, Agma dan Jender, 17(1):96-107.

Badan Penelitian dan Pengembangan Kesehatan. (2018). Hasil Utama RISKESDAS 2018. Kementerian Kesehatan Republik Indonesia diunduh 8 Mei 2020 dari http://kesmas.kemkes.go.id/assets/upload/dir_519d41d8cd98f00/files/Hasil-riskesdas2018_1274.pdf

Barry L.H., Eric M. \& R. Travis W. (2014). Diagnosis, Treatment, and Prevention of Gout. Am Fam Physician, 90 (12): 831-836.

Bishop, M., Edward, P. \& Fody, Larry ES. (2013). Clinical chemistry 7thedition: Principles, Techniques, and Correlations. Philadepia: Jones \& Bartlett Learning.

Bruke, B.T., Anna, K., Andrew, L., Morgan, G., Alan, N.B., Josef, C., and Mara A. (2015). Gout in Older Adults: The Atherosclerosis Risk in Communities Study. J Gerontol A Biol Sci Med Sci, 71(4):536-542.

Cho, S. K., Winkler, C. A., Lee, S. J., Chang, Y., \& Ryu, S. (2019). The Prevalence of Hyperuricemia Sharply Increases from the Late Menopausal Transition Stage in Middle-Aged Women. Journal of clinical medicine, 8(3): 296.

Infodatin. (2016). Situasi Lanjut Usia di Indonesia : Buletin Jendela Data dan Informasi Kesehatan $\begin{array}{llllll}\text { Kemenkes } & \text { RI. } & \text { Diunduh } & 8 & \text { Mei } & 2020\end{array}$ https://www.kemkes.go.id/resources/download/pusdatin/infodatin/infodatin\%20lansia\% 202016.pdf

Kurahashi H., Masami W., Morito S., Yuichi A., Sabina M., Motoo A., Kazushi I., Yasutomo N., Atsushi N. and Hiromi K. (2013). Testosterone replacement elevates the serum uric acid levels in patients with female to male gender identity disorder. Endocrine Journal, 60 (12):1321-1327.

Ni Q, Lu X, Chen C, Du H, Zhang R. (2019). Risk factors for the development of hyperuricemia. Medicine, (98):42.

Nita, V., \& Inrayani, N. (2020). Pendidikan Kesehatan Dalam Upaya Pencegahan Kanker Serviks Pada Wanita Usia Subur. DINAMISIA: Jurnal Pengabdian Kepada Masyarakat, 4(2), 306-310.

Purwaningsih. (2017). Perbandingan Kadar Glukosa Darah Sebelum Dan Sesudah Minum Kopi. The Journal Of Muhammadiyah Laboratory Technologist, 2(1), 62-63.

Ramadhanti, M., Amelia, R., Luhulima, D. (2018). Gambaran Kadar Hemoglobin Pada Perokok Aktif di Terminal Kayuringin Kota Bekasi. Jurnal Mitra Kesehatan: 2(1), 1-6.

Susana, E., Nursyamsi, I., Kristianti, W., \& Komarudin, A. (2020). Gerakan Sakamed sebagai Upaya Meningkatkan Kesadaran Pentingnya Kalibrasi Alat Kesehatan di Puskesmas. DINAMISIA: Jurnal Pengabdian Kepada Masyarakat, 4(2), 346-353.

Wu A, Shi Z, Martin S, Vincent A, Heilbronn L, Wittert G (2018) Age-related changes in estradiol and longitudinal associations with fat mass in men. PLOS ONE 13(8): e0201912. doi.org/10.1371/journal.pone.0201912.

Yu, X. L., Shu, L., Shen, X. M., Zhang, X. Y., \& Zheng, P. F. (2017). Gender difference on the relationship between hyperuricemia and nonalcoholic fatty liver disease among Chinese: An observational study. Medicine, 96(39): e8164.

Yuichi T., Makoto H., Masaki K. dan Hidetsugu S. (2011). The Effect of Female Hormones Upon Urate Transport Systems in the Mouse Kidney. Nucleosides, Nucleotides and Nucleic Acids, 30(2):113-119.

Zirkin, B.R. \& Joyce, L.T. (2012). Aging and Declining Testosterone: Past, Present, and Hopes for the Future. J Androl, 33 (6): 1111-1118. 